\title{
日本 8 地域と中国, 韓国における製材品 の価格弾性值と需給に関する分析 Analysis of Lumber Price Elasticity and Demand/Supply among Eight Japanese Regions, China and Korea
}

行武 潔・吉本 敦

Yukutake, K. \& Yoshimoto, A.

キーワード：製材品需給モデル, 価格弾性値,市場空間均衡モデル, JAFSEM

要約: 本報告は日本の需給構造を 8 地域 (東北, 関東, 北陸, 中部, 近畿, 中国, 四国, 九州) に分け, 近隣の韓国, 中国と共に製材品需給の価格弾性値を 比較検討し，それらを踏まえてサミュエルソンタイプの市場空間均衡 モデル, JAFSEM (Japanese Forest Sector Model) を用いて, 今後の需給変 化の特徵を提示しようというものである. 分析の結果, 国産材製材産地 の九州地域と米材製材産地の中国地域は全般に供給に対する価格弾性 值は小さく, それに対し大消費地の関東地域は製材品需要の価格弹性 值が大きいことが分かった. また, 市場空間均衡モデルによるシミュレ ーションでは, 九州地域を除く日本の各地域では製材品需要が増え, そ の増加分は韓国, 中国から供給される可能性があることが指摘された。

Abstract: In this study, we first estimate price elasticity of lumber supply and demand for eight Japanese regions (Tohoku, Kanto, Hokuriku, Chubu, Kinki, Chugoku, Shikoku, and Kyushu), as well as China and Korea. With the estimated price elasticity for these regions, we secondly analyze the characteristics of the supply and demand structure through the spatial and inter-temporal partial equilibrium market model called JAFSEM (Japanese Forest Sector Model). Our analysis show that the price elasticity of lumber demand and supply of all products is small in the Kyushu and Chugoku 
regions, where the domestic timber and the US processed lumber is actively produced, while the price elasticity of lumber demand is large in the Kanto region as the major lumber consumption area. With the derived elasticity for JAFSEM, our simulation results show that Japanese regional lumber demand except Kyushu would increase, which would be met by Korea and China supplies.

Keywords: JAFSEM, lumber demand and supply model, price elasticity, spatial and inter-temporal market equilibrium model

\section{1.はじめに}

地球温暖化対策として1997年に京都議定書が議決されて以来, 大気中の $\mathrm{CO}_{2}$ 削減に寄与する森林の $\mathrm{CO}_{2}$ 吸収・貯蔵機能が再認識され, 森林の持続的経 営が改めて重視されることとなった. 化石燃料やエネルギー消費量の大きい 非木質系資材や非木造住宅に代わるバイオマス, 林産物, 木質系住宅, 家具等 の利用は大気中の $\mathrm{CO}_{2}$ 増加を防ぐ効果がある。この意味においても地球温暖 化防止の重要な鍵を握るものとして, 持続的な森林資源管理や循環型社会に おける木材利用のあり方が見直されてきている.

しかしながら，環境保護の論理と経済発展の論理は往々にして相反する方 向を目指す場合がある。市場原理に基づく自由貿易が地域的に健全な森林資 源の維持管理を損ない, 持続的な森林経営を困難にすることも起こりうる. 例 えば，日本においては，プラザ合意以降，貿易の自由化により大量に入ってき た外材が国内の製材品市場のシェアーを確保し，国内製材品のシェアーが落 ち込み, その結果, 日本の森林を持続的に経営することが困難になり, 昨今で は, 伐採後の再造林放棄も目立ち始めてきている。戦後のわが国の林業経営 は,木材市場, 特に木材輸入のあり方如何に大きく左右されてきた.

このように変化してきた木材の需給構造に関して, 以下のような研究結果 がある. 国レベルでは国産材, 米材, 北洋材, 南洋材とも輸入量, 需給量, 価格の 集積されたデータがあり，これら外材と国産材の関係について, 森 (1972), 行 武 (1977) は1960～1970年代の年次データに基づく需給モデルから, 北米材の 輸入価格弾性值が大きく米材輸入量が著しく増える状態にあることを示し た. 立花 $(1994,1997)$ は1973～1991年及び1975～1993年の年次データに基づ き, 北米の木材輸出構造が丸太中心から製材品中心へと転換していることを 
指摘した. また, 行武ら (2006) は1970～2002年までの国産材, 米材, ロシア材, ニュージーランド材の年次データを用いて, 米材供給サイドの変化が与える 影響をシミュレーション分析した。この他我が国における木材貿易に関する 需給モデルの計量経済学的分析は, Yukutake (1984), 森 (1992) などの研究があ る.

上記研究が全国レベルの研究であるのに対し，地域レベルでのデータを用 いたものとしては, 行武・吉本 (1996), Yoshimoto et al. (1999), Yoshimoto and Yukutake (2002) がある.これらは, 各港に入荷される輸入量の他は製材工場 レベルの国産材丸太, 製材品と国内挽き米材製材品の数量と価格を用いたも ので, 地域市場を考慮した市場空間均衡モデルに基づくものである.行武・吉 本(1996) はKoopams-Hitchcock型の均衡モデル (Labys 1989) を用いたのに対 し, Samuelson型の空間均衡モデル (Samuelson 1952) を用いたのがYoshimoto et al. (1999) とYoshimoto and Yukutake (2002) である. 現在構築されたモデル はJAFSEM (Japanese Forest Sector Model) として更に拡張が試みられている.

本研究はこれらのことに鑑み，以下の点を明らかにする。これまでの JAFSEMで取り扱われた日本の 8 地域 (東北, 関東, 北陸, 中部, 近畿, 中国, 四 国, 九州) に中国, 韓国を加え, 木材需給の価格弾性值を推定し, 各弾性值の比 較検討をする. 得られる価格弾性值をもとに中国・韓国を加え, JAFSEMを拡 張し, 全地域において想定される木材需給の変化を把握する.

\section{2. 地域における需給モデル}

取り扱った品目はYoshimoto et al. (1999) 同様に国産材製材品，国内挽き米 材製材品, 輸入製材品の 3 つである. 但し, 韓国, 中国は利用可能な資源が少な くデータがないことから, 自国産の丸太からの製材品生産ではなく, 国内産の 製材品, 輸入製材品を用いた. ここでは, 次の 2 つの基本モデルを考慮した. 第 1 に, これら各品目について需給の部分均衡モデル, 第 2 に, 空間均衡モデル の構築に対応した総製材品需要関数, 国産材製材品供給関数, 国内挽き米材製 材品と製材品輸入供給関数と韓国, 中国の国内製材品需要, 国内産製材品供給 関数並びに製材品輸入供給関数によるモデルである. 


\section{1. 部分均衡モデル}

総製材品, 国産材製材品, 国内挽き米材製材品, 韓国製材品, 中国製材品及び 製材品輸入量の各需給関数は, 以下に示すとおりである. [1], [4], [7]式はそれ ぞれ総製材品, 国産材製材品, 国内挽き米材製材品の需要関数, [2], [5], [8]式は 各供給関数である. 各需要関数は基本的に自身の製材品価格 $\left(P_{i}^{W}, P_{i}^{D}, P_{i}^{U}\right)$, 各地域の木造建築着工面積 $\left(H_{i}\right)$ または全国木造建築着工面積 $(J H)$ を説明変 数とした. 供給関数は自身の価格の他, 総製材品, 国内挽き米材製材品の場合 は製造労賃 $\left(W_{i}^{P}\right)$ と米材丸太輸入量 $\left(Q_{i}^{L}\right)$ を説明変数とし, 国産材製材品の 場合は自身の価格の他は伐出労賃 $\left(C_{i}^{H}\right)$ または $W_{i}^{P}$ を説明変数として用い た.

[10], [11]式は韓国の製材品需給関数である. 韓国の製材品需要関数は, 自身 の価格 $(P K P)$ とGDP $(K G D P)$ によって, 製材品供給関数は自身の価格と丸太 価格及び自国内の賃金 $(W K P)$ によって説明されている. [13], [14]式は中国の 製材品需給関数である. 需要関数はGDPのデータが不足しているため, 代わり に人口 $(C N)$ を, 供給関数についても価格以外の賃金等の説明要因データがな いためタイムトレンド (Year) のみ用いた. 価格データに関しても物価指数デ 一タが不足しているため,他と異なりそのまま名目価格とした.

[16]〜 [18]式に示す製材品輸入モデルは, 全てFAOデータによる輸入量と輸 入製材品価格を用いた. 供給関数は製材品輸入価格の他輸出国の賃金と為替 レートを説明変数とした. 需要関数の場合, 輸入製材品価格の他は, 日本につ いては全国水準の木造建築着工面積 $(J H)$, 韓国はGDP, 中国は人口を説明変数 に用いた。

\section{1) 総製材品需給量}

$$
\log \left(Q_{i}^{D}\right)=a_{1}+a_{2} \cdot \log \left(P_{i}^{W}\right)+a_{3} \cdot \log \left(H_{i}, \text { or JH }\right)
$$

$$
\begin{aligned}
& \log \left(Q_{i}^{S}\right)=a_{11}+\underset{+}{a_{12}} \cdot \log \left(P_{i}^{W}\right)+\underset{-}{a_{13}} \cdot \log \left(W_{i}^{P}\right)+\underset{+}{a_{14}} \cdot \log \left(Q_{i}^{L}\right) \\
& \log \left(Q_{i}^{D}\right)=\log \left(Q_{i}^{S}\right)
\end{aligned}
$$

ただし $Q_{i}^{D}: i$ 地域の国産材・外材込みの製材品需要量, $P_{i}^{W}: i$ 地域の平均製材 品価格, $H_{i}: i$ 地域の木造建築着工面積, $J H$ : 全国木造建築着工面積, $Q_{i}^{S}: i$ 地 
域の国産材 - 外材込みの製材品供給量, $W_{i}^{P}: i$ 地域の製造労貨, $Q_{i}^{L}:$ 米材丸太 輸入量.

2) 国産材製材品需給モデル

$$
\begin{aligned}
& \log \left(Q_{i}^{D D}\right)=b_{11}+b_{12} \cdot \log \left(P_{i}^{D}\right)+b_{13} \cdot \log \left(H_{i}, \text { or JH }\right)+b_{14} \cdot \log \left(P_{i}^{U}\right) \\
& \log \left(Q_{i}^{D S}\right)=b_{1}+b_{2} \cdot \log \left(P_{i}^{D}\right)+b_{3} \cdot \log \left(P_{i}^{L D}\right)+b_{4} \cdot \log \left(C_{i}^{H}, \text { or } W_{i}^{P}\right) \\
& \log \left(Q_{i}^{D S}\right)=\log \left(Q_{i}^{D D}\right)
\end{aligned}
$$

ただし $Q_{i}^{D S}: i$ 地域の国産材製材品供給量, $P_{i}^{D}: i$ 地域の国産材製材品価格, $C_{i}^{H}$ : 伐出賃金, $Q_{i}^{D D}: i$ 地域の国産材製材品需要量.

\section{3) 国内挽き米材製材品需量}

$$
\begin{aligned}
& \log \left(Q_{i}^{U D}\right)=c_{11}+\underset{-}{c_{12}} \cdot \log \left(P_{i}^{U}\right)+\underset{+}{c_{13}} \cdot \log \left(H_{i}, \text { or JH }\right) \\
& \log \left(Q_{i}^{U S}\right)=c_{1}+c_{2} \cdot \log \left(P_{i}^{U}\right)+\underset{+}{c_{3}} \cdot \log \left(W_{i}^{P}\right)+c_{4} \cdot \log \left(Q_{i}^{L}\right)+c_{5} \cdot D M_{2002}^{H K} \\
& \log \left(Q_{i}^{U S}\right)=\log \left(Q_{i}^{U D}\right)
\end{aligned}
$$

ただし $Q_{i}^{U S}: i$ 地域の国内挽き米材製材品の供給量, $Q_{i}^{U D}: i$ 地域の国内挽き米 材製材品の需要量, $P_{i}^{U}: i$ 地域の国内挽き米材製材品価格. なお, 推定上の都 合から $D M_{2002}^{H K}$ : 北陸地域 2002 年に対し 1 となるダミー変数を設定した.

\section{4) 韓国製材品需給モデル}

$$
\begin{aligned}
& \log \left(Q^{K D}\right)=e_{11}+\underset{-}{e_{12}} \cdot \log (P K P)+e_{13} \cdot \log (K G D P) \\
& \log \left(Q^{K S}\right)=e_{1}+\underset{+}{e_{2} \cdot \log (P K P)+e_{3} \cdot \log (P L K P)+e_{4} \cdot \log (\text { WKP })} \\
& \log \left(Q^{K S}\right)=\log \left(Q^{K D}\right)
\end{aligned}
$$

ただし $Q^{K S}$ : 韓国の国内製材品の供給量, $Q^{K D}$ : 韓国の国内製材品の需要量, $P K P:$ 韓国の国内製材品価格, PLKP: 韓国の丸太品価格, WKP: 韓国の実質貨 金価格, KGDP: 韓国の国内製材品の実質GDP.

\section{5) 中国製材品需給モデル}

$$
\begin{aligned}
& \log \left(Q^{C D}\right)=f_{11}+f_{12} \cdot \log (P M P)+f_{13} \cdot \log (C N) \\
& \log \left(Q^{C S}\right)=f_{1}+f_{2} \cdot \log (P M P)+f_{3} \cdot \text { Year } \\
& \log \left(Q^{C S}\right)=\log \left(Q^{C D}\right)
\end{aligned}
$$

ただし $Q^{C S}$ : 中国の国内製材品の供給量, $Q^{C D}$ : 中国の国内製材品の需要量, $P M P$ : 中国の国内製材品輸入価格, Year: タイムトレンド, $C N$ : 中国の人口. 


\section{6) 製材品輸入モデル}

$$
\begin{aligned}
\log \left(Q^{M S}\right) & =d_{1}+d_{2} \cdot \log (P M S)+d_{3} \cdot \log (W A)+d_{4} \cdot \log (\text { EXJA }) \\
+ & d_{-} \\
\log \left(Q^{M D}\right) & =d_{11}+d_{12} \cdot \log (P M S)+d_{13} \cdot \log (J H, \text { KGDPor } C N) \\
\log \left(Q_{i}^{M S}\right) & =\log \left(Q_{i}^{M D}\right)
\end{aligned}
$$

ただし $Q^{M S}$ : 輸入製材品の供給量, $Q^{M D}$ : 輸入製材品の需要量, $P M S$ : 輸入製材 品価格, $W A$ : 米国, カナダ産地国賃金, EXJA: 為替レート( $¥ / \$)$.

\section{2. 空間均衡モデルに対応した需給モデル}

空間均衡モデルに用いる価格と数量の需給関数は, それぞれの推定された 価格弾性值から求められる. 寸なわち, 先に示した[1]式の総製材品需要 $\left(Q_{i}^{D}\right)$ 関数, [5]式の自国産材製材品供給関数, [8]式の国内挽きの米材製材品供給関 数それぞれを推定して得られる。これら 3 式を 8 地域ごとに3SLSを用いて同 時推定により弾性值を推定する. 最終的には得られる推定結果と部分均衡モ デルによる推定結果を比較検討し, 空間均衡モデルJAFSEMに用いるための 各需給価格弾性值を決定する. なお, 韓国, 中国は国内挽き米材製材品供給に 相当するデータがないため, 先の部分均衡モデルによる推定結果を, 空間均衡 モデルJAFSEMでは採用することとする.また，輸入製材品供給の価格弾性值 の推定には先の部分均衡モデルによる[16]式を用いることとする. 但し, 日本 8 地域ごとの価格データは得られないため, 日本 8 地域の価格弾性值 $d_{2}$ は皆 同じとした.

上記モデルの推定に当たって用いたデータは，以下の通りである。 $Q_{i}^{D}$, $P_{i}^{W}, Q_{i}^{S}, Q_{i}^{U S}, P_{i}^{D}, P_{i}^{U}$ は「木材需給報告書」(農林水産省 $1975 \sim 2003$ ), $C_{i}^{H}$, $W_{i}^{P}$ は「都道府県別,職種別,賃金形態別 1 日平均決まって支給する現金給与額 (素材生産)」及び「都道府県別,産業大分類別一人月間平均給与額」(厚生労働省 1975～2003) から， $H_{i}$ は「建築統計年報」(建設省 1975～2003) から， $Q_{i}^{L}$ は日本 木材輸入協会から, $Q_{i}^{M S}, P M S$ FAOインターネットホームページの “FAOSTAT Database”から, KGDP, CN, WA, EXJAは “International Financial Statistics Yearbook” (International Monetary Fund 2003) から求めた. 日本 8 地域 の需給モデル[1]〜 [9]式に関しては1974～2002の年次データ, 中国, 韓国及び 製材品輸入式に関しては1970～2002年の年次データを用いた. また, 中国, 韓 
国の製材品需要量は (輸入量+国内生産量-輸出量)により求め, 国内製材品生 産量を国内製材品供給量とした. 従って, 空間均衡モデルJAFSEMの需要, 供 給関数を求めるために, 先の韓国, 中国製材品需給関数 $[10] \sim[15]$ 式において, 前者の製材品需要量を国内総製材品需給量とし, 後者の国内製材品生産量を 国内産製材品需給量とした 2 通りの部分均衡需給モデルを想定して, 国内総 製材品需要, 国内産製材品供給関数の推定を試みた.

\section{3. 需給モデルの推定結果}

\section{1. 各種推定結果の弾性值比較}

上記の需給モデルの推定結果を, 普通最小自乗法 (OLS), 2 段階最小自乗法 (2SLS), 3 段階最小自乗法 (3SLS) の異なる推定方法による結果及び過去の推 定結果 (Yoshimoto et al. 1999, 行武・吉本 2002) も含めて比較すると, 図1, 2, 3 のようになる.これらのOLS, 2SLS, 3SLSによる推定結果は, 符号条件は理論 的に整合性が得られ, $t$-值も 2.0 以上と全般にほぼ満足いく結果を得た. ここで は3SLSによる結果を表1, 表2に示した.これらから, 以下のことが指摘できる.

1. 図からOLSや2SLSよりも3SLSによる推定結果の方が弾力的な值を示し た. すなわち, 1974-2002年間の製材品需要の価格弾性值を3SLSの結果で 見ると, 部分均衡モデルによるものではー0.75〜-4.12で, 1974〜1998年 の結果よりもかなり弾力的であった.

2. 表1に示す部分均衡モデルによる推定結果と, 表2に示す製材品需要, 国 産材, 米材製材品供給関数を同時に推定した結果では, 同じ3SLSによる 方法でもかなり相違が見られた. $t$-值や決定係数の当てはまりはやや後 者の方がよいものが多い. また, 図より2SLS と製材品需要, 国産材製材 品供給，国内挽き米材製材品供給を同時に推定した結果は，比較的類似 の傾向がみられる.よって, 空間均衡モデルで用いる各需給の価格弾性 值としては表2の結果を採用した. 


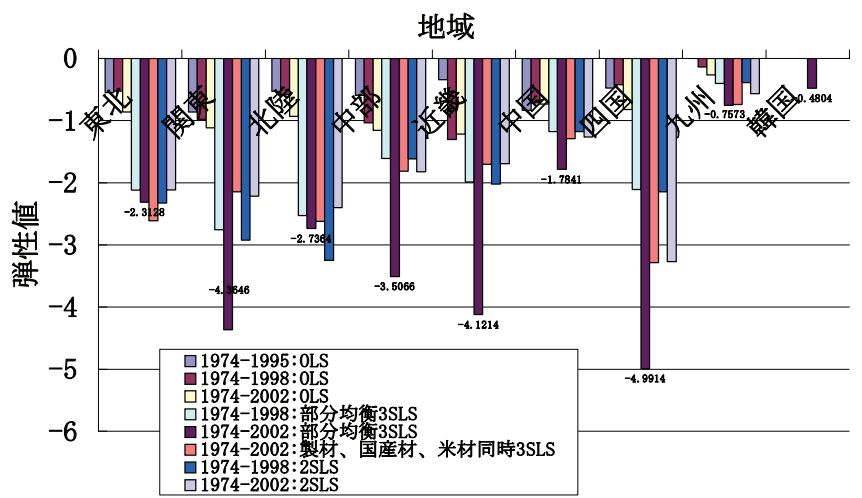

図1. 日本 8 地域と韓国における製材品需要の価格弾性值

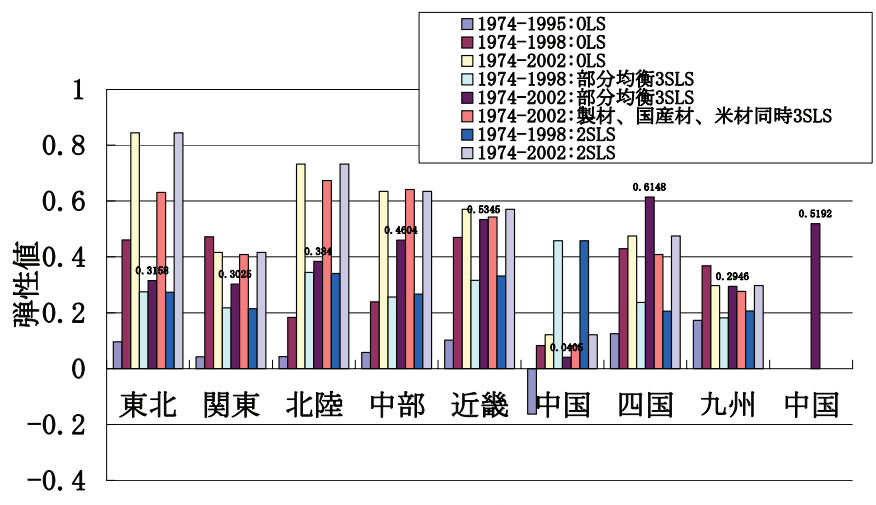

地域

図2. 国産材製材品供給価格弾性值 : 2002年中国は自国内

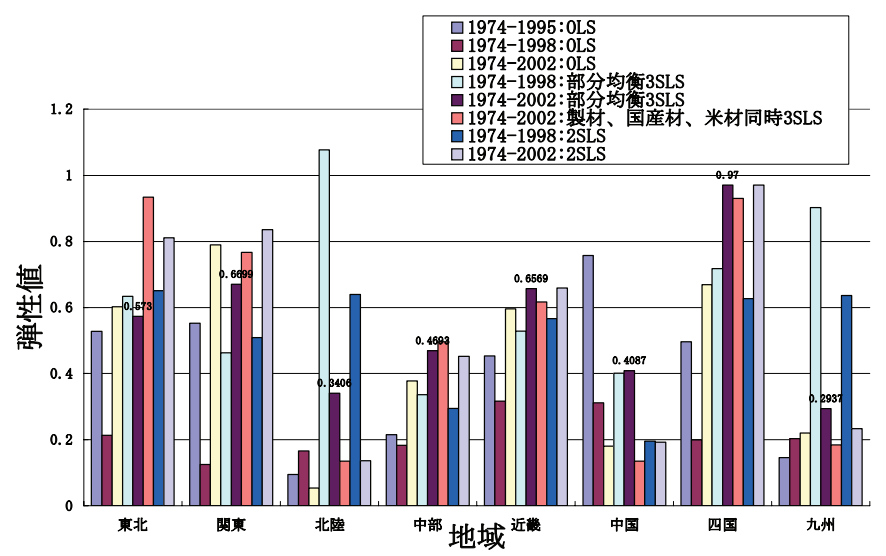

図3. 国内挽き米材製材品供給価格弾性值 
3. 弾性值の地域間比較をすると，国産材製材産地と米材製材産地の九州， 中国地域はともに全般に弾性値は小さく, 大消費地の関東は製材品需要 の価格弾性值が大きい. また, 製材品需要の価格弾性值は, 関東に次いで 中部が大きい傾向があり，1974～2002年では四国が最も弾力的であつ た. 国産材製材品供給では近畿, 中部, 北陸の価格弾性值が, 比較的大き い. 米材製材品供給の価格弾性值は1974～2002年では四国が最も大きく 0.9 以上, 次いで関東, 近畿の $0.6 \sim 0.7$ となった。 また,これら結果から,以下のような課題が示される.

（1）2SLS等よりも3SLSの方が統計的な有意性は高まる傾向にあるが，推定 值も大きくなる傾向にある。

(2) 3 SLSによる推定結果, 符号条件も $t$-值もほぼ満足いく結果を得た。しか 表1.3SLSによる 8 地域の部分均衡モデルの需要, 供給関数の推定結果

\begin{tabular}{|c|c|c|c|c|c|c|c|c|c|}
\hline \multicolumn{2}{|c|}{ 3SLS } & 東北 & 関東 & 北陸 & $\begin{array}{l}\text { 地域 } \\
\text { 中部 }\end{array}$ & 近畿 & 中国 & 四国 & 九州 \\
\hline \multirow{9}{*}{ 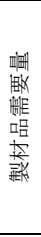 } & $a_{1}$ & -4.4110 & -24.5322 & -5.3273 & -11.9669 & 5.3538 & 0.3148 & -2.9818 & -1.8701 \\
\hline & & $(-2.152)$ & $(-3.090)$ & $(-2.032)$ & $(-2.577)$ & (1.123) & $(0.184)$ & $(-0.911)$ & $(-2.008)$ \\
\hline & $a_{2}$ & -2.3128 & -4.3646 & -2.7364 & -3.5066 & -4.1214 & -1.7841 & -4.9914 & -0.7573 \\
\hline & & $(-3.946)$ & $(-3.137)$ & $(-3.545)$ & $(-3.770)$ & $(-3.651)$ & $(-3.974)$ & $(-2.500)$ & $(-3.121)$ \\
\hline & $a_{3}$ & 2.3373 & 5.0564 & 2.6883 & 3.7713 & 2.1022 & 1.7248 & 3.8877 & 1.4382 \\
\hline & & (6.793) & (4.057) & (6.278) & (5.009) & (3.384) & (8.785) & (3.297) & (7.902) \\
\hline & $\mathrm{R}^{2}$ & 0.6118 & 0.2792 & 0.5780 & 0.4087 & 0.2731 & 0.7302 & 0.2792 & 0.7996 \\
\hline & DW & 1.1539 & 1.4449 & 1.2404 & 1.2797 & 0.4870 & 1.1693 & 1.5315 & 1.4860 \\
\hline & SE & 0.2078 & 0.3458 & 0.2213 & 0.3030 & 0.3988 & 0.1597 & 0.3355 & 0.0864 \\
\hline \multirow{10}{*}{ 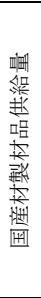 } & $\mathrm{b}_{1}$ & 10.7071 & 8.0516 & 9.8087 & 7.3597 & 7.2362 & 8.3185 & 4.4495 & 6.4991 \\
\hline & & $(17.460)$ & $(17.225)$ & $(12.924)$ & $(9.805)$ & $(10.952)$ & $(12.313)$ & $(9.601)$ & (16.594) \\
\hline & $b_{2}$ & 0.3158 & 0.3025 & 0.3840 & 0.4604 & 0.5345 & 0.0405 & 0.6148 & 0.2946 \\
\hline & & $(2.156)$ & $(2.886)$ & (2.390) & (2.662) & $(3.410)$ & $(0.264)$ & (5.839) & (3.617) \\
\hline & $\mathrm{b}_{3}$ & & -1.0019 & & -0.8316 & -1.1012 & -0.7738 & -0.0802 & 0.0471 \\
\hline & & & $(-20.353)$ & & $(-10.687)$ & $(-15.647)$ & $(-11.596)$ & $(-2.492)$ & $(0.846)$ \\
\hline & $\mathrm{b}_{4}$ & $\begin{array}{c}-0.7924 \\
(-13.221)\end{array}$ & & $\begin{array}{c}-0.9055 \\
(-17.346)\end{array}$ & & & & & \\
\hline & $\mathrm{R}^{2}$ & 0.8519 & 0.9350 & 0.9080 & 0.8204 & 0.8964 & 0.7124 & 0.5429 & 0.3193 \\
\hline & DW & 0.3225 & 0.6732 & 0.4327 & 0.2260 & 0.4795 & 1.4242 & 0.4186 & 0.4533 \\
\hline & SE & 0.0996 & 0.0765 & 0.0915 & 0.1129 & 0.0955 & 0.1224 & 0.0877 & 0.0712 \\
\hline \multirow{12}{*}{ 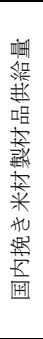 } & $\mathrm{c}_{1}$ & 0.5028 & -0.4135 & 2.5245 & 0.8265 & -1.0109 & 3.0589 & -0.5960 & 0.4594 \\
\hline & & $(0.353)$ & $(-0.323)$ & $(4.040)$ & (1.122) & $(-1.593)$ & (5.697) & $(-0.600)$ & $(0.903)$ \\
\hline & $\mathrm{c}_{2}$ & 0.5730 & 0.6699 & 0.3406 & 0.4693 & 0.6569 & 0.4087 & 0.9700 & 0.2937 \\
\hline & & (1.798) & (2.929) & (1.923) & (3.669) & (5.373) & (3.138) & $(4.586)$ & (2.740) \\
\hline & $c_{3}$ & 0.6343 & 0.7157 & 0.4471 & 0.7481 & 0.8004 & 0.5470 & 0.7110 & 0.7689 \\
\hline & & $(9.276)$ & (11.679) & (6.763) & (17.324) & $(28.793)$ & (6.635) & (8.496) & (33.739) \\
\hline & $\mathrm{c}_{4}$ & & -0.0103 & & -0.1276 & & -0.2340 & -0.2361 & \\
\hline & & & $(-0.082)$ & & $(-1.494)$ & & $(-3.217)$ & $(-2.413)$ & \\
\hline & $\mathrm{c}_{5}$ & & & $\begin{array}{l}-0.4421 \\
(-4.708)\end{array}$ & & & & & \\
\hline & $\mathrm{R}^{2}$ & 0.7818 & 0.9290 & 0.8637 & 0.9729 & 0.9776 & 0.6931 & 0.8164 & 0.9814 \\
\hline & DW & 0.3100 & 0.6994 & 0.8795 & 1.6559 & 1.9593 & 0.6212 & 1.4918 & 1.7804 \\
\hline & SE & 0.1782 & 0.1269 & 0.1039 & 0.0722 & 0.0650 & 0.0836 & 0.0963 & 0.0607 \\
\hline
\end{tabular}

注: ( ) 内は $t$-值, $\mathrm{R}^{2}$ は自由度調整済み決定係数, DWはダービン・ワトソン比, SEは式全 体の標準誤差である. 以下同様. 
しながら, 部分均衡モデルによる場合と, 製材品需要, 国産材, 米材製材 品供給関数を同時に推定した場合では，同じデータ，同じ3SLSで推定し てもその結果にはかなりの相違が見られる。この相違は，一般に時系列 データの場合, 少なくとも50以上あるいは100以上は必要といわれ，この データ不足によることが考えられる.

\section{2. 空間均衡モデル需給関数の価格弾性值}

上記の結果, 最終的に部分均衡モデルによる推定結果でなく, 日本 8 地域に 対する総製材品需要関数, 国産材製材品供給関数, 国内挽き米材製材品供給関 数を同時に推定した結果と, 韓国, 中国の推定結果を空間均衡モデルとして選 んだ (表2).これから, 特に中国, 韓国と国産材生産地である九州をのぞく日本 の他地域における総製材品需要の価格弾性值が非常に弾力的なことが指摘で きる. 国内挽き米材製材品供給価格弾性值については東北, 関東が比較的弾力 的, 九州は他より非弾力的で, 中国は望ましい推定結果が得られなかったため 表2.3SLSによる空間均衡モデル対応の需要, 供給関数の推定結果

\begin{tabular}{|c|c|c|c|c|c|c|c|c|c|c|c|}
\hline \multirow{2}{*}{\multicolumn{2}{|c|}{ 3SLS }} & \multicolumn{10}{|c|}{ 地域 } \\
\hline & & 東北 & 関東 & 北陸 & 中部 & 近畿 & 中国 & 四国 & 九州 & Korea & China \\
\hline \multirow{9}{*}{ 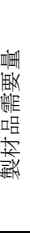 } & $a_{1}$ & -4.1686 & -5.3059 & -5.7917 & -9.7870 & 2.6704 & -1.18924 & -2.834 & -2.235 & 7.0452 & - \\
\hline & & $(-0.236)$ & $(-0.099)$ & $(-2.488)$ & $(-0.203)$ & $(0.915)$ & $(-0.998)$ & $(-1.251)$ & $(-2.828)$ & (6.381) & - \\
\hline & $a_{2}$ & -2.6122 & -2.1466 & -2.6222 & -1.8148 & -1.7038 & -1.28764 & -3.286 & -0.73836 & -0.4804 & - \\
\hline & & $(-5.786)$ & $(-0.838)$ & $(-4.405)$ & $(-0.755)$ & $(-3.498)$ & $(-5.067)$ & $(-2.891)$ & $(-3.946)$ & $(-0.932)$ & - \\
\hline & $a_{3}$ & 2.4403 & 3.2455 & 2.6889 & 2.7812 & 1.3473 & 1.6651 & 2.9858 & 1.4702 & 0.2087 & - \\
\hline & & (8.916) & (4.544) & $(7.641)$ & $(6.346)$ & (3.857) & (12.318) & (4.328) & $(10.234)$ & (3.019) & - \\
\hline & $\mathrm{R}^{2}$ & 0.5678 & 0.3890 & 0.5991 & 0.5261 & 0.3333 & 0.807696 & 0.3901 & 0.8094 & 0.9014 & - \\
\hline & DW & 1.0884 & 1.0538 & 1.2905 & 1.2835 & 0.3382 & 1.5906 & 1.6283 & 1.5726 & 1.9801 & - \\
\hline & SE & 0.2319 & 0.2442 & 0.2134 & 0.2084 & 0.249503 & 0.1249 & 0.2354 & 0.0858 & 0.2026 & - \\
\hline \multirow{11}{*}{ 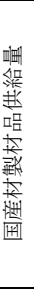 } & $\mathrm{b}_{1}$ & 9.7597 & 7.4930 & 6.0026 & 6.5550 & 7.1187 & 8.1107 & 5.6590 & 6.6676 & - & 30.2410 \\
\hline & & (14.284) & (14.987) & (6.348) & (7.965) & (10.204) & (11.16) & $(9.364)$ & $(16.633)$ & - & $(-4.324)$ \\
\hline & $\mathrm{b}_{2}$ & 0.6307 & 0.4090 & 0.6736 & 0.6416 & 0.5432 & 0.0823 & 0.408804 & 0.2763 & - & 0.5192 \\
\hline & & (3.582) & (3.649) & $(3.041)$ & (3.379) & $(3.276)$ & $(0.500)$ & (3.304) & $(3.300)$ & - & (3.423) \\
\hline & $\mathrm{b}_{3}$ & & -0.9515 & & -0.80557 & -1.06791 & -0.75908 & -0.23941 & 0.0007 & - & -0.0078 \\
\hline & & & $(-8.606)$ & & $(-0.122)$ & $(-15.375)$ & $(-1.4405)$ & $(-3.770)$ & -0.0136 & - & $(-2.206)$ \\
\hline & $\mathrm{b}_{4}$ & -0.8526 & & -1.0252 & & & & & & - & \\
\hline & & $(-14.742)$ & & $(-14.454)$ & & & & & & - & \\
\hline & $\mathrm{R}^{2}$ & 0.8224 & 0.9316 & 0.8685 & 0.8078 & 0.8960 & 0.8215 & 0.6602 & 0.3099 & - & 0.2350 \\
\hline & DW & 0.3639 & 0.6843 & 0.6081 & 0.2332 & 0.4689 & 0.3048 & 0.4093 & 0.4465 & - & 0.4832 \\
\hline & SE & 0.1133 & 0.0778 & 0.1111 & 0.1168 & 0.0955 & 0.0962 & 0.0751 & 0.071804 & - & 0.3209 \\
\hline \multirow{13}{*}{ 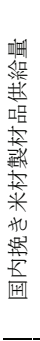 } & $\mathrm{c}_{1}$ & -1.6335 & -0.0670 & 2.2300 & 1.2323 & -0.69072 & 2.4501 & -0.23111 & 1.0371 & - & - \\
\hline & & $(-0.996)$ & $(-0.055)$ & $(3.750)$ & (1.799) & $(-1.007)$ & $(4.650)$ & $(-0.242)$ & (1.7 & - & - \\
\hline & $\mathrm{c}_{2}$ & 0.9335 & 0.7669 & 0.1351 & 0.4960 & 0.6164 & 0.1348 & 0.9295 & 0.1844 & - & - \\
\hline & & $(2.626)$ & $(3.370)$ & $(0.808)$ & (4.048) & $(4.626)$ & $(1.009)$ & $(4.295)$ & (1.498) & - & - \\
\hline & $\mathrm{c}_{3}$ & 0.7491 & 0.6806 & 0.6248 & 0.7091 & 0.7785 & 0.763301 & 0.6926 & 0.7446 & - & - \\
\hline & & (9.588) & (12.985) & (9.808) & (18.590) & $(27.644)$ & $(11.825)$ & $(9.596)$ & (31.120) & - & - \\
\hline & $\mathrm{c}_{4}$ & & -0.0991 & & -0.1704 & & -0.2136 & -0.24976 & & - & - \\
\hline & & & $(-0.959)$ & & $(-0.395)$ & & $(-3.113)$ & $(-2.984)$ & & - & - \\
\hline & $\mathrm{c}_{5}$ & & & -0.226918 & & & & & & - & - \\
\hline & & & & $(-2.445)$ & & & & & & - & - \\
\hline & $\mathrm{R}^{2}$ & 0.7657 & 0.9306 & 0.9126 & 0.9721 & 0.9776 & 0.7590 & 0.8179 & 0.9781 & - & - \\
\hline & DW & 0.5215 & 0.7049 & 1.1449 & 1.4007 & 1.7487 & 0.6212 & 1.4040 & 1.3157 & - & - \\
\hline & SE & 0.1726 & 0.1258 & 0.0826 & 0.0746 & 0.0663 & 0.9618 & 0.0945 & 0.0653 & - & - \\
\hline
\end{tabular}


1 と仮定した. 国産材製材品供給価格弾性值も東北は比較的高いが, 九州は低 い.また韓国は望ましい結果が得られなかったため 1 とした.

表3より, 製材品輸入の供給価格弾性值は, 韓国が 3.45 と最も弾力的, 中国は 0.57, 日本は0.47である.なお，日本は地域ごとの輸入価格がないため，すべて 同じ弾性值で, 各地域の供給量 $\left(Q_{i}^{M S}\right)$ は, 総製材品輸入供給量に対する各地 域の輸入比率で振り分けて得られる (Yoshimoto et al. 1999).

表3. 製材輸入供給関数の推定結果

\begin{tabular}{ccccccccc}
\hline & $\mathrm{d}_{1}$ & $\mathrm{~d}_{2}$ & $\mathrm{~d}_{3}$ & $\mathrm{~d}_{4}$ & $\mathrm{~d}_{5}$ & $\mathrm{R}^{2}$ & $\mathrm{DW}$ & $\mathrm{SE}$ \\
\hline \multirow{2}{*}{ 日本 } & 9.6949 & 0.4739 & -0.0380 & -1.1544 & & 0.9300 & 1.7674 & 0.1327 \\
& $(2.605)$ & $(1.570)$ & $(-0.142)$ & $(-16.404)$ & & & & \\
\hline \multirow{2}{*}{ Korea } & -309.4420 & 3.4344 & 66.5285 & -4.7010 & 5.5245 & 0.9018 & 1.7829 & 0.5617 \\
& $(-2.840)$ & $(2.288)$ & $(2.717)$ & $(-2.363)$ & $(3.277)$ & & & \\
\hline \multirow{2}{*}{ China } & -35.9597 & 0.5696 & 9.4229 & 1.8360 & & 0.9055 & 1.5395 & 0.5027 \\
& $(-2.030)$ & $(2.251)$ & $(2.465)$ & $(10.006)$ & & & & \\
\hline
\end{tabular}

注: Koreaのd 5 は輸出国の GDPである.

\section{4. 空間均衡モデル（JAFSEM）による分析}

\section{1. 空間均衡モデル（JAFSEM）の構築}

Yoshimoto and Yukutake (2002) が構築したJAFSEMの日本製材品市場の 8 地域 (東北, 関東, 北陸, 中部, 近畿, 中国, 四国, 九州) に中国, 韓国を加え, 表2 に示すこれらの需給の価格弾性值を基に価格と数量のみで表される需要と供 給関数を導き出し, 次式に示すように, Samuelson (1952) によって提示された 空間均衡モデルを構築する. その際, 2002年の価格と数量を基準として, 需要 と供給関数は導出される.これにより, 純社会利益 (NSP: Net Social Payoff) を 最大にする日本 8 地域に中国, 韓国を加えた東アジア木材市場の均衡解が得 られる.NSPは消費者余剰と生産者余剰を加え, 生産市場から消費市場までの 輸送費を差し引いて得られる (Yoshimoto et al. 1999).

[19] $\underset{\left[\left\{D_{i}^{*}\right\},\left\{S_{j}^{*}\right\},\left\{Q_{i, j}\right\}\right]}{\operatorname{maximize}} N S P=\sum_{i=1}^{m} \int_{0}^{D_{i}^{*}} P D_{i}\left(q_{i}\right) d q_{i}-\sum_{j=1}^{n} \int_{0}^{S_{j}^{*}} P S_{j}\left(q_{j}\right) d q_{j}-\sum_{i=1}^{m} \sum_{j=1}^{n} Q_{i, j} \cdot T_{i, t}$ subject to

$$
D_{i}^{*} \leq \sum_{j=1}^{n} Q_{i, j} \quad \forall i
$$




$$
\begin{aligned}
& S_{j}^{*} \geq \sum_{i=1}^{m} Q_{i, j} \quad \forall j \\
& \left\{D_{i}^{*}\right\},\left\{S_{j}^{*}\right\},\left\{Q_{i, j}\right\} \geq 0
\end{aligned}
$$

ここにおいて, $P D_{i}(\cdot)$ と $P S_{i}(\cdot)$ は $i$ 地域の需要と供給関数, $T_{i, j}$ は $i$ から $j$ 地域 への輸送コスト, $S_{j}$ は $j$ 地域の供給量, $D_{i}$ は $i$ 地域の需要量で, $Q_{i, j}$ は $i$ から $j$ 地域へ輸送された量である。

\section{2. シミュレーション結果}

上記[19]式を解くに当たり，日本 8 地域と中国, 韓国を含む輸送費を聞き取 り調査に基づいて表4のように仮定した.これらを基に得られた製材品需給の 均衡解を, 2002年の実績と比較すると, 眓4のようになる. 総製材品需要は33.7 百万 $\mathrm{m}^{3}$ と実績值よりも 3 百万 $\mathrm{m}^{3}$ 程増えた. 地域別にみると中国と韓国が実績

表4. 各地域間の輸送費 $\left(\mathrm{Yen} / \mathrm{m}^{3}\right)$

\begin{tabular}{ccccccccccc}
\hline 地域 & 東北 & 関東 & 北陸 & 中部 & 近畿 & 中国 & 四国 & 九州 & Korea & China \\
\hline 東北 & 2000 & 3500 & 4000 & 4500 & 6000 & 7000 & 7000 & 7000 & 12000 & 13000 \\
関東 & - & 2000 & 3500 & 3000 & 3500 & 3500 & 4000 & 5000 & 10000 & 11000 \\
北陸 & - & - & 2000 & 3000 & 2800 & 4000 & 4000 & 7000 & 10000 & 11000 \\
中部 & - & - & - & 2000 & 3000 & 4000 & 4000 & 5000 & 10000 & 12000 \\
近畿 & - & - & - & - & 2000 & 3000 & 3000 & 4000 & 9000 & 12000 \\
中国 & - & - & - & - & - & 2000 & 2500 & 4000 & 9000 & 12000 \\
四国 & - & - & - & - & - & - & 2000 & 4000 & 9000 & 12000 \\
九州 & - & - & - & - & - & - & - & 2000 & 7000 & 10000 \\
Korea & - & - & - & - & - & - & - & - & 2000 & 5000 \\
China & - & - & - & - & - & - & - & - & - & 2000 \\
\hline
\end{tabular}

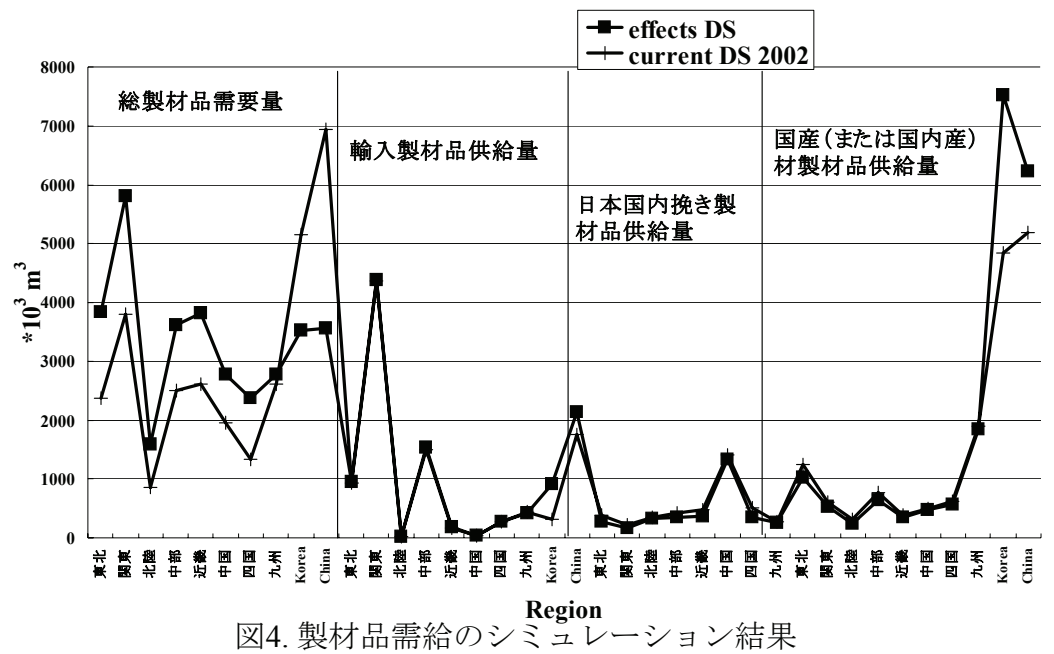


值よりも $2 \sim 3$ 百万 $\mathrm{m}^{3}$ 減り, 九州以外の日本各地域が $1 \sim 2$ 百万 $\mathrm{m}^{3}$ 増えた. 総輸入製材品量は 10.8 百万 $\mathrm{m}^{3}$ と実績值よりも百万 $\mathrm{m}^{3}$ ほど増え, 韓国, 中国のみ ならず日本の 8 地域も実績よりも増加を示した。 日本国内挽き米材製材品の

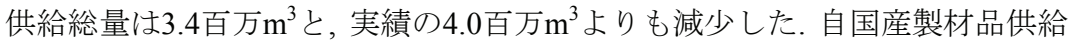
総量は19.4百万と実績值よりも2.1百万ほど増え, 特に韓国, 中国が $1 \sim 2$ 百万 ほど増加し, 他は減少を示した。

\section{5. 結論}

表2から日本の総製材品需要の価格弾性值は, 産地である九州のー0.74を除 くと, -2.0 前後とかなり弾力的, 韓国のそれは一 0.48 となった. 一方, 国産 (中 国は国内産) 材製材品供給の価格弾性值は0.6以下，日本挽き米材製材品供給 の価格弾性值は 1.0 以下で, 0.5 以下も 4 地域あった. また, 輸入製材品供給の価 格弾性值は日本が 0.47 , 韓国が3.4, 中国が0.57であった。これらの弾性值を基 に, 市場空間均衡モデル (JAFSEM) を拡張し, シミュレーションを行った結 果, 九州を除く日本 7 地域の総製材品需要量は2002年実績よりも増加し, その 増加分は韓国, 中国から供給されることが示された.

今後の課題としては, 以下のことがあげられる. 中国の総製材品需要価格弾 性值, 韓国の国内産製材品供給価格弾性值については満足行く結果を得るこ とができなかったので, 1.0 と仮定したが, 今後改善する必要がある. 中国のデ 一タ, 特に国内産の価格, 需給量, 及びそれを説明する説明要因に関するデー タが不十分で,それらのデータ収集及び整備が望まれる.ここで用いたモデル に考慮するにはデータが不足しているが, 近年増加している集成材等のその 他木材製品の輸入効果を考慮する必要がある.

\section{引用文献}

Labys, W.C. 1989. Spatial and temporal price and allocation models of mineral and energy markets. In Quantitative methods for market-oriented economic analysis over space and time. Labys, W.C., Takayama, T. and Uri, N.D. (eds). Avebury. Vermont. pp.17-47 
森 義昭. 1972. 木材輸入の構造変化に関する計量分析. 農林問題研究 32 : 135-145

Mori, Y. 1992. Timber market in Japan -An econometric analysis-. Memoirs of the College of Agriculture. Kyoto Univ. 139: 179-191

Samuelson, P.A. 1952. Spatial price equilibrium and linear programming. The American Economic Review 42: 283-303

立花 敏. 1994. 日本と北米の木材貿易に関する計量経済学的分析. 林業経済 研究 125: 36-41

立花 敏. 1997. 日本の針葉樹材需給構造に関する計量経済学的研究. 東大農 演報 97: 298p.

Yoshimoto, A., Kajita, J. and Yukutake, K. 1999. Japanese forest sector modeling Possibility of increasing domestic timber production -. In Global concerns for forest resource utilization. Yoshimoto, A. and Yukutake, K. (eds). Kluwer Academic Publishers. pp.183-200

Yoshimoto, A. and Yukutake, K. 2002. Japanese forest sector modeling through a partial equilibrium market model. J. of Forest Research 7: 41-48

Yukutake, K. 1984. Econometric analysis of South Sea and USSR log Market in Japan. Japan Agricultural Research Quarterly 17(4): 269-279

行武 潔. 1977. 第 1 部 建築用林産物需給の構造分析. 製材・合板・紙パル プの計量経済分析. 唯是 康彦, 行武 潔編著. 黄帆社. pp.5-240

行武 潔・吉本 敦. 1996. 北米における対日木材輸出の国内産地に及ぼす影 響〜Koopmans-Hitchcock型均衡モデルによるシミュレーション分析 ．日林論 107: 413-414

行武 潔・吉本 敦. 2002. 我が国における地域別木材需給分析一普通最小二 乗法, 2 段階最小二乗法, 3 段階最小二乗法による価格弾性值の比較 分析一.森林計画学会誌 $36(2): 81-98$

行武 潔・福島一登・藤掛一郎. 2006. わが国木材市場における米材輸入効果 の計量分析. 森林資源管理と数理モデルVol.5: 127-141 